\title{
Concepts and treatment for diabetes among traditional and faith healers in the Northern Province, South Africa
}

\author{
K Peltzer, Department of Psychology, University of the North \\ LB Khoza, Department of Nursing, University of the North \\ ME Lekhuleni, Department of Nursing, University of the North \\ SN Madu, Department of Psychology, University of the North \\ VI Cherian, Department of Psychology of Education, University of the North \\ L Cherian, Department of Psychology of Education, University of the North
}

\begin{abstract}
The purpose of the study was to assess the concepts and treatment modalities for diabetes among traditional and faith healers in the Northern Province in South Africa. The sample consisted of 50 traditional healers (13 females and 37 males) and 50 faith healers ( 12 females and 38 males). They were interviewed on local terminology, clinical manifestations, causes, curability, and treatment for diabetes, help-seeking behaviour of diabetes patients, and the healers' sources of information about diabetes. Results indicate that all healers were familiar with "diabetes", however, not all of them had seen patients suffering from diabetes. The perceived causes of diabetes by both traditional and faith healers could be divided into (1) diet (especially too much of sugar), (2) heredity, (3) supernatural, and (4) psychological causes. Most traditional healers $(92 \%)$ and faith healers $(90 \%)$ indicated that diabetes is curable. Treatments used by the healers in this study included the use of prayer, diet, and herbs. The authors conclude that the concepts and treatment modalities for diabetes among traditional and faith healers should be taken note of by health workers while developing health education programmes in the Province.
\end{abstract}

\section{Introduction}

Modern medicine does not cure diabetes, but provides symptomatic relief without restoration of glucose homeostasis at hepatocellular levels. Many studies, in different parts of the world, have demonstrated the hypoglycaemic effect of certain medicinal plants (e.g., Ajabnoor, 1990).

Clinical experiences and some research findings indicate that traditional and faith healers play a role in the management of diabetes in Africa. Ziqubu-Page, Dangor, Makubalo and Chetty (1999: 57) found that among diabetic patients in South Africa $28.7 \%$ had been using traditional medicine only, $49.7 \%$ conventional medicine and $21.5 \%$ had used both. The majority of the traditional medicine users $(93 \%)$ believed that the herbal preparations they used were effective. Peltzer (1999: 390) found that from 80 faith healers interviewed in the Northern Province five reported that they commonly treat 'bolwetši bja swikiri' (diabetes).

Among British Bangladeshis, diabetes was generally attributed to events or agents outside the body rather than to primary failure of an organ within the body. All diabetic patients believed that the primary cause of diabetes, and that of poor diabetic control, was too much sugar and, to a lesser extent, other features of Western diet, both of which feature strongly in folk models of other cultural groups. Other etiological factors by the Bangladeshi informants included heredity (the notion of an agent transmitted through "shared blood", rather than an inherited predisposition) and germs.
Many informants mentioned physical or psychological stress, either as a perceived cause of diabetes or simply when reporting the experience of daily life - especially in relation to economic difficulties, poor housing, and fear of crime (Greenhalgh, Helman \& Chowdhury 1998: 980).

Diabetes mellitus is clearly a chronic disease for which orthodox medicine is not curative, but until recently alternative therapy for diabetes has not been widespread. However, recently alternative therapies claim to alleviate or cure diabetes. Concerns were raised when patients with diabetes were treated with alternative medicine and faith healing and health deteriorated (Gill, Redmond, Garratt \& Paisey 1993: 212). However, some plant and herbal preparations may have mild hypoglycaemic effects (Bailey \& Day 1989: 553). Ryan, Imes, Wallace and Jones (2000) investigated herbal tea treatment for diabetes and found that the responder analysis failed to show an effect of the herbal tea; the data suggest that there may be a short-term benefit from the tea in subjects with poor glycemic control.

Freeman and Motsei (1992: 1183) stated that there are broadly three types of traditional healers available to South African consumers. First, the traditional doctor or inyanga. This is generally a male who uses herbal and other medicinal preparations for treating diseases. Second the dingaka (Sotho). This is usually a woman who operates within a traditional religious supernatural context and acts as a medium with the 
ancestral shades. Third, the faith healer who integrates Christian ritual and traditional practices.

Clinical experiences and above research findings indicate that traditional and faith healers play a role in the management of diabetes in Africa. The research on concepts and treatment modalities of diabetes among traditional and faith healers might contribute towards greater awareness and understanding of health workers regarding their (healers') perceptions and treatment methods.

The purpose of the study was to assess in more detail the concepts and treatment modalities about diabetes among traditional and faith healers in the Northern Province in South Africa.

\section{Method \\ Design}

This was an explorative and descriptive study using key informants, which should facilitate access to traditional and faith healers (Madu, 1998).

\section{Sample and procedure}

The sample consisted of 50 traditional healers (13 females and 37 males) in the age range of 30 to 75 years (Mean age = 52.1 years, $S D=12.4$ ) and 50 faith healers (12 females and 38 males) in the age range of 27 to 65 years (Mean age $=43.9$ years, $S D=10.9$ ).

Five postgraduate students in educational psychology were chosen and trained in interviewing techniques. To facilitate access to the respondents, the interviewers were asked to identify and interview 10 traditional healers and 10 faith healers in their (own) communities. Traditional healers were traditionally remunerated in form of gifts. Initially each postgraduate student was to identify a healer who was either a relative or someone they were familiar with and subsequently snowball sampling was used until a sample of 20 healers was reached. All traditional and faith healers were located in the central, lowfeld and southern region of the Northern Province of South Africa.

\section{Measure}

After a literature review, a semi-structured interview sched-

\section{Table 1: Clinical manifestations of diabetes by traditional healer (TH) and faith healer (FH) by frequency}

\begin{tabular}{|c|c|c|c|}
\hline Physiological systems & Clinical manifestations & $\begin{array}{l}\text { TH } \\
(n=50)\end{array}$ & $\begin{array}{l}\mathbf{F H} \\
(\mathbf{n}=50)\end{array}$ \\
\hline $\begin{array}{l}\text { Problems related to respiratory, cardio-vascu- } \\
\text { lar and renal system }\end{array}$ & $\begin{array}{l}\text {-Swollen tummy, hands and legs } \\
\text {-Difficulty breathing } \\
\text {-Urinating time and again } \\
\text {-Other (stinking urine, shortage of } \\
\text { blood, heart beating fast, pale skin) }\end{array}$ & $\begin{array}{l}12 \\
3 \\
4 \\
3\end{array}$ & $\begin{array}{l}11 \\
1 \\
3 \\
1\end{array}$ \\
\hline $\begin{array}{l}\text { Problems related to neurological and endo- } \\
\text { crine system }\end{array}$ & $\begin{array}{l}\text {-Easily tired, weakness } \\
\text {-Painful body parts } \\
\text {-Sexual dysfunction } \\
\text {-Short tempered, aggressive } \\
\text {-Dizziness } \\
\text {-Headache } \\
\text {-Other (problem with vision, bad } \\
\text { dreams. low body temperature) }\end{array}$ & $\begin{array}{l}9 \\
8 \\
5 \\
3 \\
4 \\
1 \\
0\end{array}$ & $\begin{array}{l}9 \\
0 \\
0 \\
2 \\
0 \\
3 \\
4\end{array}$ \\
\hline $\begin{array}{l}\text { Problems related to metabolic and digestive } \\
\text { system }\end{array}$ & $\begin{array}{l}\text {-Over sweating } \\
\text {-Overweight } \\
\text {-Nausea } \\
\text {-Loss of appetite } \\
\text {-Loss of weight } \\
\text {-Other (diarrhea, like eating sweet } \\
\text { food, persistent thirst, too much appe- } \\
\text { tite, constipation) }\end{array}$ & $\begin{array}{l}12 \\
6 \\
8 \\
6 \\
3 \\
3\end{array}$ & $\begin{array}{l}6 \\
11 \\
1 \\
3 \\
1 \\
7\end{array}$ \\
\hline Problems related to musculo-skeletal system & $\begin{array}{l}\text {-Thin body } \\
\text {-Skin colour changes } \\
\text {-Other (soft skin, shiny skin, inability } \\
\text { to sit straight) }\end{array}$ & $\begin{array}{l}6 \\
3 \\
3\end{array}$ & $\begin{array}{l}0 \\
0 \\
1\end{array}$ \\
\hline Problems related to sensory system & $\begin{array}{l}\text {-Poor eyesight } \\
\text {-Brown eyes }\end{array}$ & $\begin{array}{l}2 \\
3\end{array}$ & $\begin{array}{l}6 \\
0\end{array}$ \\
\hline
\end{tabular}


Table 2: Perceived causes of diabetes by traditional healer (TH) and faith healer (FH) by frequency

\begin{tabular}{|l|l|l|l|}
\hline Causative concepts & Categories of causative concepts & $\begin{array}{l}\text { TH } \\
(\mathbf{n = 5 0 )}\end{array}$ & $\begin{array}{l}\text { FH } \\
(\mathbf{n = 5 0 )}\end{array}$ \\
\hline \multirow{4}{*}{ Diet } & Too much sugar & 25 & 28 \\
\cline { 2 - 4 } & Too much salt, chillies & 14 & 7 \\
\cline { 2 - 4 } & Alcohol & 3 & 3 \\
\hline Heredity & Any family member can spread to next generation & 12 & 13 \\
\hline Super-natural & Ancestors (when refusing their instructions) & 7 & 1 \\
\cline { 2 - 4 } & Devil \& demons & 0 & 5 \\
\cline { 2 - 4 } & Sefolane (stepping on something magically) & 5 & 3 \\
\cline { 2 - 4 } & Contagion (Sex with widow, woman who & 14 & 2 \\
\hline Psychological & miscarried or aborted) & & 7 \\
\cline { 2 - 4 } & Thinking a lot & 7 & 0 \\
\hline
\end{tabular}

ule was designed. The contents included (1) local terminology for diabetes, (2) symptoms and signs, (3) causes, (4) curability, (5) treatment, (6) help-seeking behaviour of patients prior to consulting the traditional or faith healer, and (7) sources of information about diabetes. Furthermore, the traditional and faith healers were asked to describe in details, a diabetic patient/client they have attended to.

The interview schedule was designed in English and translated to the local language (Northern Sotho) and back translated by a bilingual expert. It was given to two external experts to validate, and they indicated that the instrument is valid. A pilot study was conducted on five traditional healers and five faith healers to test the reliability of the interview schedule. The same healers (from the pilot study) were asked to respond to the interview schedule after 3 weeks. The responses from the first and second interview were comparable, and this is an indication of the reliability of the interview schedule.

After collecting the responses from the traditional and faith healers in the local language, the data were translated into English by the research assistants and checked and verified by Northern Sotho experts.

\section{Data analysis}

Reported case studies were content analysed, and descriptive statistics were calculated using SPSS.

\section{Results}

\section{Characteristics of healers}

All healers were Northern Sotho by ethnicity. Most traditional healers (36) belonged to traditional or African religion, and most faith healers belonged to the Zion Christian Church (ZCC) (19) and the Apostolic church (16), followed by the Born Again Christian Movement (7), the International Pentecostal Holiness (4), and others (4).

Thirty-one of the traditional healers said that they were fulltime practitioners and 19 were part-time practitioners. Similarly, 30 faith healers considered themselves as full-time and
20 part-time practitioners. All healers indicated that they were familiar with "diabetes", however, not all of them have attended to patients suffering from diabetes (15 traditional and 5 faith healers had not attended to a diabetic client).

\section{Local names for diabetes}

Both traditional and faith healers identified 'Bolwetši bja swikiri' (Litt. disease of sugar) as the term used for diabetes

Clinical manifestations of diabetes as described by healers (see Table 1).

Clinical manifestations of diabetes were grouped according to related physiologic systems. Both traditional and faith healers identified a number of clinical manifestations of diabetes such as swollen tummy, hands and legs, easily tired, weakness, over sweating, and overweight. Traditional healers identified predominantly painful body parts, sexual dysfunction, thin body, skin colour changes and brown eyes, whereas faith healers reported more poor eyesight than traditional healers did.

Table 2 indicates the perceived causes of diabetes by the healers. The perceived causes of diabetes by both traditional and faith healers could be divided into (1) diet (in particular too much sugar), (2) heredity, (3) supernatural, and (4) psychological. Traditional healers rated supernatural causes as predominantly contagion and ancestors, while faith healers rated devil and demons.

Table 3 indicates the curability and treatment modalities of diabetes by traditional and faith healers.

Interesting is that most traditional healers $(86 \%)$ and faith healers $(94 \%)$ indicated that diabetes is curable. There were major differences in the treatment by traditional and faith healers. Some traditional healers mainly used herbs as an adjunct to diabetic medication and faith healers prayer as treatment of diabetes. The change of diet was mentioned by both traditional and faith healers.

Table 4 indicates the help-seeking behaviour of diabetic patients as reported by the healers. 
Table 3: Curability and treatment of diabetes by traditional healer (TH) and faith healer (FH) by frequency

\begin{tabular}{|l|l|l|l|}
\hline Curability and treatment modalities & Treatment details & $\begin{array}{l}\text { TH } \\
(\mathbf{n = 5 0 )}\end{array}$ & $\begin{array}{l}\text { FH } \\
(\mathbf{n = 5 0 )}\end{array}$ \\
\hline Curable & & 43 & 47 \\
\hline Incurable & & 7 & 3 \\
\hline Herbs & Mix diabetes medication with herbs & 4 & \\
\hline Prayer & & & 7 \\
\hline Diet & $\begin{array}{l}\text {-Reduce sugar, salt, chillies } \\
\text {-Eat fruits \& vegetables }\end{array}$ & 7 & 6 \\
\hline
\end{tabular}

Both traditional and faith healers indicated that they usually saw a diabetic patient after they had already been to a clinic, and a number came to them -especially to faith healers - when they were already very sick. On the one hand, some traditional healers indicated that they had seen some patients after they (the patients) had consulted with the pastor, and on the other hand some faith healers had seen patients after the patients had been to the traditional healer.

Table 5 indicates the sources of information on diabetes by the healers.

Both traditional and faith healers indicated that they mostly receive information on diabetes through spiritual means, bones/ancestors or dreams in the case of the traditional healers and the Bible or Holy Spirit in the case of faith healers. Mainly faith healers as opposed to traditional healers heard about diabetes through doctors, radio/television, and magazines. Some faith and traditional healers also indicated that colleagues had provided them with information on diabetes.

\section{Case examples from traditional healers}

1) "D., a man from village G. came here with the problem of diabetes. He was peeling skin and was very weak. His legs were swollen. I made sewatsho for him as was prescribed by the ancestors. The other instructions were performed. The man as I am talking now is very well."

2) "The diabetic patient was tired and had nausea. She was

\section{Table 4: Help-seeking of diabetic patients prior to consulting the traditional healer (TH) and faith healer (FH) by frequency}

\begin{tabular}{|l|l|l|}
\hline Help-seeking behaviour & $\begin{array}{l}\text { TH } \\
(\mathbf{n = 5 0 )}\end{array}$ & $\begin{array}{l}\text { FH } \\
(\mathbf{n}=\mathbf{5 0})\end{array}$ \\
\hline After been to clinic & 28 & 22 \\
\hline After been to pastor & 6 & 0 \\
\hline After been to healer & 0 & 7 \\
\hline When very sick & 3 & 13 \\
\hline
\end{tabular}

feeling like vomiting and the family members accompanied her. After taking my medication, i.e., half a cup of the medication, three times a day, within two weeks time the person was cured."

3) "A client came with a sore that could not heal for several months on the leg. The client was treated and was healed. Later on, the client went to the hospital without informing the traditional healer. At the hospital amputation was done and thereafter the client died."

\section{Case examples from faith healers}

1) "A patient came to me, and he had no appetite, with swollen legs and very stout. I sprinkled him with blessed water, laid hands on him, and burnt three cut stripped newspapers around his head. I injected him with sanctified needle nose, both hands and both legs. I made a weak Joko tea for him for seven days. He was not to eat red meat nor drink tea with sugar. He had to eat with vegetables. After seven days, I burnt stone from the big river for him to inhale the steam. He had to bathe with water from the lake by sunlight and use ZCC Vaseline. After a couple of weeks, he was fit and strong. Dancing mokhukhu all night long. Even today, he is still all right."

2) "The person came to me at an advanced stage of diabetes. The person has partially lost his sight. The legs were very swollen and he complained of pains all over the body. I used holy water, because it is very important to us. From there I referred him to Moria (Zion Christian Church) to be baptised. When the person came back, he was healed. He even went to a doctor for confirmation that he is healed."

\section{Discussion Clinical manifestations and causative concepts}

Polyuria, polyphagia, polydipsia, blurred vision, poor wound healing and loss of weight though supported in the literature (Luckmann \& Sorensen 1987: 1407f.) to be causing remarkable problems experienced by diabetic patients, were not identified as major problems by both the traditional and faith healers. Poor eyesight as indicated by the healers is supported by Smeltzer and Bare (1996: 1050) as a physical factor that might impair the ability to learn or perform self-care skills. Overweight 


\section{Table 5: Sources of information on diabetes by traditional healer (TH) and faith healer (FH) by frequency}

\begin{tabular}{|l|l|l|}
\hline Agents of information & $\begin{array}{l}\text { TH } \\
(\mathbf{n = 5 0 )}\end{array}$ & $\begin{array}{l}\text { FH } \\
(\mathbf{n = 5 0 )}\end{array}$ \\
\hline Doctors & 3 & 9 \\
\hline Radio/TV & 3 & 8 \\
\hline Magazine & 0 & 4 \\
\hline Bones/Ancestors & 15 & 0 \\
\hline Dreams & 11 & 1 \\
\hline Other traditional healer & 3 & 0 \\
\hline Other faith healer & 0 & 12 \\
\hline Holy Spirit & 0 & 10 \\
\hline Bible & 0 & 10 \\
\hline
\end{tabular}

was one of the frequently mentioned symptoms of diabetes by the healers. Luckmann and Sorensen (1987: 1407) support that most people over 40 who develop diabetes are overweight, because all overweight people require more insulin to metabolise the food they eat. Traditional healers identified sexual dysfunction as one of the clinical manifestations of diabetes. Literature (Luckmann \& Sorensen 1987: 1407) supports that abnormalities involving the sexual organs and libido such as menstrual cycle irregularities, loss of libido and impotence, can be part of the clinical manifestations of diabetes.

In this study contagion (sex with widow, woman who miscarried or aborted) was identified as a major cause. The concept of contagion needs further investigation in the context of transfer of bad blood contributing to diabetes. The issue of inheriting diabetes from a family member as frequently mentioned by both traditional and faith healers is supported by the literature (Smeltzer \& Bare 1996: 1050).

\section{Treatment modalities}

Treatments used by the healers in this study included the use of prayer, diet, and herbs. A major role of herbal preparations in the traditional treatment of diabetes has been found among diabetic patients in Kwa Zulu-Natal (Ziqubu-Page et al., 1999). In this study, exercise was not identified as one of the treatment modalities. Diet as a treatment of diabetes by healers is supported by Smeltzer and Bare (1996: 1023). They emphasise that meal planning and the use of non-nutritive sweeteners constitute the foundations of diabetes mellitus management. The 10 most frequently recommended or used alternative therapies as seen by American diabetes educators were physical activity, self-help groups, lifestyle diets, laughter and humour, relaxation therapy, prayer, imagery and visualisation, meditation, massage, and music therapy (Sabo, Michael \& Temple 1999: 945).

Gori and Campbell (1998: 201) point out that some natural products are potentially damaging to people with chronic diseases, especially if they are used instead of proven scientific treatment regimens. Natural products that have been promoted in relation to diabetes are, for example, ackee fruit, alfalfa, aloe vera, argimony, artichokes, barley, bitter melon, devil's club, eucalyptus, garlic, and ginseng. The few products that have a mild impact on lowering blood glucose levels are sig- nificantly less effective than standard treatments. In order to ensure that no toxic effects occur and that treatment objectives are achieved, health professionals should closely monitor any person who decides to use natural products for diabetes. Evens et al. (1995: 405) conclude that acupuncture is potentially very useful in the treatment of painful diabetic neuropathy, especially in those patients unresponsive to previous medical therapy.

Patients who consult traditional or faith healers do so mostly after they have been to a medical institution and even in some cases at another traditional or religious institutions. This seems to indicate that patients with diabetes seek multiple health care, traditional and modern.

\section{Conclusion and recommendations}

It was discovered that traditional and faith healers do seem to play a relevant role in the management of diabetes.

Traditional and faith healers appear to be confident of their treatment modalities for curating diabetes. It appears as though traditional and faith healers are not keen to refer clients to medical practitioners. Diabetes clients seem to consult traditional or faith healers before or after consulting the medical practitioners. The issues regarding concepts and treatment modalities for diabetes might be perceived by health workers as an essential component of developing effective health education programmes in the Northern Province of South Africa. It is recommended that (I) health workers should collaborate with traditional and faith healers, (2) further research be carried out on the effectiveness of traditional treatment modalities, and (3) that health workers should have a clear understanding about cultural beliefs affecting treatment modalities of diabetes as practised by traditional and faith healers.

\section{Acknowledgement}

The Medical Research Council, South Africa, funded the research project.

\section{References}

AJABNOOR, MA 1990 : Effect of aloes on blood glucose levels in normal and alloxan diabetic mice. Journal of Ethnopharmacologv 28: 215-220.

BAILEY, CJ \& DAY, C 1989 : Traditional plant medicine treatments of diabetes. Diabetes Care 12: 553-556.

EVENS, DL ET AL. 1995 : Acupuncture: a novel treatment for painful diabetic neuropathy. In: N. Hotta et al. (eds.) Diabetic neuropathy: new concepts and insights (pp. 405-408). Amsterdam: Elsevier Science.

FREEMAN, M \& MOTSEI, M 1992 : Planning health care in South Africa: is there a role for traditional healers? Social Science \& Medicine 34: 1183-1090.

GILL, GV; REDMOND, S; GARRATT, F \& PAISEY R 1993 : Diabetes and alternative medicine. Complementary Therapies in Medicine 2: 210-213. 
GORI, M \& CAMPBELL, RK 1998 : Natural products and diabetes treatment. Diabetes Educator 24: 201-207.

GREENHALGH, T; HELMAN, C \& CHOWDHURY AM 1998 : Health beliefs and folk models of diabetes in British Bangladeshis: a qualitative study. British Medical Journal 316: 978-983.

HELMAN, CG 1995 : The body image in health and disease: exploring patients' maps of body and self. Patient Education and Counselling 26: 169-175.

LUCKMANN, J \& SORENSEN KC 1987 : Medical-surgical nursing: a psychophysiologic approach. Philadelphia: W.B. Saunders.

MADU, SN 1998 : A method for approaching African traditional healers for psychological investigations. In: Madu, Baguma, and Pritz, (eds.). In quest for psychotherapy for modern Africa. Pietersburg: UNIN Press. 92-99.

PELTZER, K 1998 : A community survey of traditional healers in South Africa (Northern Province). South African Journal of Ethnology 21: 191-197.

PELTZER, K 1999 : Faith healing for mental and social disorders in the Northern Province (South Africa). Journal of Religion in Africa 29: 387-402.

RYAN, EA; IMES, S; WALLACE, C \& JONES, S 2000 : Herbal tea in the treatment of diabetes mellitus. Clinical \& Investigative Medicine 23(5): 311-317.

SABO, CE; MICHAEL, SR \& TEMPLE, LL 1999 : Use of alternative therapies by diabetes educators. Diabetes Educator 25: 945-956.

SMELTZER, SC \& BARE, BG 1996 : Brunner and Suddarth's textbook of medical-surgical nursing. Philadelphia: Lippincott.

ZIQUBU-PAGE, TT; DANGOR, CM; MAKUBALO, LE \& CHETTY, M 1999 : Determinants of traditional medicine use by diabetic patients in the Northern Kwa Zulu-Natal Province. Curare 22: 49-61. 